\title{
Finding Points of Resonance: Nunavut Students' Perspectives on Science
}

\author{
Marc Higgins \\ University of British Columbia
}

\section{Author Note}

Correspondence concerning this article should be addressed to Marc Higgins, 4479 5th Ave. West, Vancouver, BC, V6R 1S4. E-mail: higginsm@interchange.ubc.ca or mrhiggin@lakeheadu.ca

\begin{abstract}
Still largely based on EuroCanadian knowledge and Western teachings, Education in Nunavut remains a negative experience for many Nunavut youth as the result of culturally inappropriate schooling and worldview mismatch. Mismatch occurs as the schooling experiences of Nunavut youth, both Inuit and non-Inuit, do not align with the character, values, and traditions of Nunavut. Divergence is especially pronounced within science education. This paper explores Nunavut students' perceptions of the nature of science and school science education in order to explore the possibilities and problematics involved in shifting towards a cross-cultural science curriculum that is reflective of Nunavut.
\end{abstract}

Keywords: Nunavut, Inuit traditions, science education, cross-cultural science curriculum 


\section{Finding Points of Resonance: Nunavut Students’ Perspectives on Science}

Schooling in Nunavut remains largely based on Western knowledge and approaches to teaching, and, consequently, is still typically a negative experience for many Nunavut youth. The locus of the problem is not one of capacity for achievement, but rather one of culturally inappropriate schooling - there is need for appropriate learning experiences that match the character, values, and traditions of Nunavut (Aylward, 2007; Berger, 2007; Mason, 2006; see also Barnhardt \& Kawagley, 2005, 2008). As a result, the Nunavut Department of Education (2000a, 2000b) has called for education which balances Western educational approaches and Inuit Qaujimajatuqangit (IQ), "all aspects of traditional Inuit culture including values, world-view, language, social organization, knowledge, life skills, perceptions and expectations” (Nunavut Social Development Council, 1998) which continues to shape daily life in Nunavut.

Currently, one of the more difficult "balancing acts" is the one which occurs within the science classroom. The interfacing that occurs between IQ and Western modern science (WMS) is often referred to as one of "Jagged Worldviews Colliding” (Little Bear, 2000) as notions within worldviews are often placed in binary opposition with one another (e.g., wholism vs. fragmentation) (Little Bear, 2000). Despite conflicting features, WMS and IQ do not have to be viewed as mutually exclusive as there are many scientific concepts from both worldviews that resonate with one another (Watt-Cloutier, 2004; see also Barnhardt \& Kawagley, 2005; Peat, 2002).

For youth living in Nunavut's city of Iqaluit, the navigation of the interface between Inuit Qaujimajatuqangit and Western modern science is one that occurs daily. In terms of population, $58 \%$ of those living in Iqaluit are Inuit compared to $85 \%$ of the population in the rest of Nunavut (Statistics Canada, 2007). As Nunavut's capital, Iqaluit is an environment that is rich in Inuit knowledge and tradition. Furthermore, as the hub for research in the eastern Arctic, Western scientific practices are abundant. There is, here, great potential for productive dialogue between worldviews within the science classroom. Instead, Inuit Qaujimajatuqangit is underrepresented and undervalued and WMS is misrepresented (Aikenhead, 2006a; Aikenhead \& Ogawa, 2007; McComas, 1998). What would a science education that draws from the complexities and possibilities at this cultural interface resemble?

In the summer of 2009, I set off to Iqaluit, Nunavut to explore this question. One of the ways in which I explored this question was through a 2-week long participant-directed videography project in which Inuit $(n=4)$ and non-Inuit $(n=3)$ youth explored, defined, and documented the ways that science is enacted in their communities. ${ }^{1}$ During this period, I was working within the dual role of science and technology program instructor and educational researcher. As an instructor, I was returning for my third summer in a row to deliver a moviemaking program to teach youth (both Inuit and non-Inuit) the basic techniques and skills required to create their own video-media. Using video, Inuit and non-Inuit youth would explore, define, and document the various ways that science is enacted in their communities. As an educational researcher, I collected video and analyzed data of the youth's media work, as well as other forms of data. The following paper draws from interviews with the youth, as well as ongoing discussions throughout the 2-week period around these seven Nunavut youth's perspectives on what science is, its nature and implications, within their science classrooms and community. 
Drawing from these perspectives, I look to tentatively inform school science practices which aim to balance and adequately represent both IQ and WMS.

\section{Finding Points of Resonance in the Science Education Literature}

While Indigenous scholars Kawagley, Norris-Tull and Norris-Tull (1998) posit that "there is no one way to do or think about science" (p. 139), non-Western culturally relevant bodies of scientific knowledge continue to be contested as knowledge within science education. While there are scholars who uphold the notion WMS is the most valid and reliable way of knowing about nature (e.g., Cobern \& Loving, 2001, 2007; Matthews, 1994; Siegel, 1997, 2001), there are others who see the intrinsic value in Indigenous and neo-Indigenous ways-of-knowing nature (e.g., Aikenhead \& Ogawa, 2007; Snively \& Corsiglia, 2001; Stanley \& Brickhouse, 1994, 2001). This debate often lumps together all bodies of scientific cultural knowledge that are not the dominant Western science. Indigenous science in general and IQ, the Inuit traditional knowledge in which Inuit science is located, are no exceptions to this rule (Snively \& Corsiglia, 2001; Stanley \& Brickhouse, 2001). Cajete (1999) defines Indigenous science as “a broad category that includes everything from metaphysics to philosophy to various practical technologies practiced by Indigenous peoples past and present” (p. 83). Similar to Western science, Indigenous science "has models which are highly contextual to tribal experience, representational and focused on higher order thinking and understanding” (Cajete, 1999, p. 85). In light of the disservice and harm the Western "one-size-fits-all” model has done and continues to do to Indigenous youth, there is a need to shift towards a cross-cultural perspective within science education in which Indigenous science is recognized and valued (Aikenhead, 2006b; Aikenhead \& Michell, 2011; Brayboy \& Castagno, 2008; Cajete, 1999; Barnhardt \& Kawagley, 2005).

In transforming a curriculum so that it better reflects the multiple worldviews inherently present in many Indigenous communities, we can use the points of resonance where Western science and Indigenous knowledges meet as a point of departure to ease the transitions between bodies of knowledge. We can look at how the worldviews involved interplay, and learn to move between them. Giroux (2005) metaphorically refers to this type of cultural transition as border crossing. While some may smoothly cross, it can be hazardous or impossible for others. Giroux's (1992) coining of the term described the borders that the working class must confront, but it has since evolved to become a "referent for understanding the co-mingling-sometimes clash —of multiple cultures, languages, literacies, histories, sexualities and identities” (Giroux, 2005, p. 2). In the science education literature, Aikenhead's $(1997,2001)$ prominent use of the expression as a referent has made it synonymous with the cultural borders that are crossed when entering the "world of science". Here, "success at learning the knowledge of nature of another culture depends, in part, on how smoothly one crosses cultural borders" (Aikenhead, 2001, p. 340). The "smoothness" of this crossing is largely dependent on two factors: (a) the difference between the student's cultural identity and the culture of school science, (b) the student's ability to navigate between cultures and the assistance that they receive from their teachers. Based on these factors, border crossings can be smooth or simple for students whose culture is reflected within curriculum and pedagogy. For students whose culture is not reflected, these border crossings can be hazardous or even impossible (Jegede \& Aikenhead, 1999; Phelan, Davidson \& Cao, 1991). 
However, it is important to note that cross-cultural science education will remain (neo-) colonial and inappropriate if it continues to have as its final objective the unidirectional border crossing of youth into the "world of science" because this is an implicit assimilation into the ontology of Western science (Sammel, 2009). Through science education enculturation, nonIndigenous educators often implicitly tell Indigenous youth what they can gain by entering into the "modern world of science." Seldom do educators ask the reverse: What does Western science gain, as a body of knowledge, when it is dialogically interfaced with Indigenous knowledge? Mazzocchi (2006) echoes this call for conversation by stating that "there is little doubt that modern science can gain a lot from such dialogue” (p. 466). It is not only Indigenous peoples who can gain from learning Western "modern" science but there is also much to be learned and gained by non-Indigenous educators and students from Indigenous peoples' traditional knowledges such as IQ (Barnhardt \& Kawagley, 2008; Mazzocchi, 2006; Peat, 2002).

Fleer (1997) argues that, “moving between world views creates high level thinkers” (p. 17). If cultural appropriateness alone does not stand as sufficient reason to justify cross-cultural education, the argument that it creates better learners should add more substance. Furthermore, this argument applies to both Indigenous and non-Indigenous youth. On this matter, Aikenhead (2001) asserts:

The flexibility to move back and forth between cultures is a definite asset in society today. Some educators call this flexibility "empowerment," others call it walking on two different paths. It can occur when cross-cultural science instruction creates a change in the relationships of social power and privilege in the science classroom. (p. 350)

This process allows youth "to participate in the culture of power, [the Western culture] while simultaneously learning how to reflect critically on the power relations of which they are part" (O’Loughlin, 1992, p. 807). Indigenous youth can learn not only aspects of Western culture, but also can do so without losing something of their own cultural way of knowing (Aikenhead, 2001; Barnhardt \& Kawagley, 2008). For non-Indigenous youth, this critical self-reflection of the nature of Eurocentric thought and how it interfaces with other bodies of knowledge is an essential first step in broadening their horizons. For all youth, this reflection increases critical thinking skills while developing a better understanding of the underlying power relations as the “discourses of power cannot be taught by means of an uncritical curriculum” (Hickling-Hudson \& Ahliquist, 2003, p. 84).

Kanu (2003, 2006) argues for a re-imagination of postcolocolonial curriculum by stressing the importance of relations that "are no longer unidirectional or univocal, flowing from the colonialist to the colonized" (Kanu, 2003, p. 79) and critiquing those that remain so. Science, and how it is defined, acts as "a de facto gate-keeping device” (Coburn \& Loving, 2001, p. 52) into the "world of science." In response, Rudolph (2000) proposes a curricular inclusion of the examination of that which keeps students out: the nature of science (see also Plakitsi, 2010). This re-examination, integrated into the curriculum, can help youth see "not what science is, but what it includes" (Rudolph, 2000, p. 417). In involving the youth within the process they may become better positioned to see and perhaps shape what science can be (Sammel, 2009). 
Hoolbrook \& Rannikmae (2007) state that "no content is fundamental, but rather the content needed for enhancing scientific literacy is dependent on the culture and society in which the science education is implemented" (p. 1352). Because science education often fails to enlighten youth about Western modern science which permeates their everyday lives (Aikenhead 2006a; Aikenhead \& Ogawa, 2007; McComas, 1998) and which is not informed by the Indigenous knowledges shaped by the places they live (Cajete, 1999; Barnhardt \& Kawagley , 2008), redefining what counts as science from the perspective of those who are learning is essential in delivering cross-cultural science education for both Indigenous and non-Indigenous youth.

\section{Methods and Data}

This research took place within the context of a 2-week-long movie-making program during the summer of 2009. The research involved a group of seven youth from Iqaluit, Nunavut, ages 12 to 15, because this is often the age group in which disinterest in science begins (see Leap, 1982). Participants were both Inuit (IN), $(n=4)$ and non-Inuit $(n I),(n=3)$. These youths' perceptions and perspectives on science within their classrooms and community were shared through a variety of manners. For this article, I particularly draw from the two following sets of data:

1. Researcher to participant video interviews (R2PI): The following interviews lasted roughly 10 minutes each. I, as researcher, developed and delivered questions pertaining to perspectives of science. Six out of seven participants agreed to be interviewed in this manner.

2. Participant to participant video interviews (P2PI): The following interviews lasted roughly 5 minutes. Research participants developed and delivered questions pertaining to perspectives of science. Five of seven participants agreed to be interviewed in this manner.

Furthermore, participants who were taking part in the many informal conversations shared many perspectives on science throughout the science and technology education program.

\section{Findings: Damping By Design}

In the following section, the participants' perceptions of science and science education are shared and analyzed. Youth spoke of: (a) school science (probably) being for nerds, (b) what counts as science in their community, (c) who can do science (as well as when and how), and (d) how IQ and WMS compare and contrast in their communities.

\section{School Science: It’s Probably for Nerds}

When participants were interviewed about the science education that they were receiving in their school classrooms, it was clear that the science education they received within their school classrooms was not very memorable. Most of the youth (three out of five, P2PI, August 4, 2009) stated that they did not like science. Only one was tentative about his liking of science. Gregory (IN) stated: “[I] don’t find it interesting” (P2PI); Michael (nI) said that science is 
“boring” (P2PI). Samantha’s (IN) experience with science was generally disconnected from her life, her interests, and her culture, as illustrated in this particular exchange:

Michael: "What do you think of when you think of science?”

Samantha: "Nerds?”

Michael: "Why? Are there a lot of nerds in science?”

Samantha: “Probably[?]” (P2PI, August 4, 2009)

The identity associated with "thinking like scientists" that has implicitly been proposed to Samantha (IN) within her science education is one that she wished to avoid, and one in which she did not see herself. It was not an identity that she wished to be associated with and a culture to be avoided (Aikenhead, 2004; Fensham, 2004; Jegede \& Aikenhead, 1999). A recent study by Aikenhead and Elliot (2010) shows that this is often the case: Ninety percent of students in a typical North American high school prefer to see the world through worldviews other than the scientific one. When Samantha was removed from her immediate peer group and asked if she liked science at school, Samantha said "Yeah, it's fun" (R2PI, August 5, 2009). This contradiction may have something to do with the social stigma that she perceives to be attached to school science or the recalling of a memorable experience within her science classroom. She was not the only one to renounce her earlier statement about science when removed from her peer group - this was also the case for Gregory (IN) and Michael (nI), but with caveats. Gregory did not like the way he was learning scientific material and Michael found it "kind of easy" (R2PI, August 5, 2009). Neither reported being fully engaged in their science learning experience in school.

Returning to Samantha's (IN) statement about “nerds” probably being in science, her inquisitive and unsure response in the interview may demonstrate a certain lack of knowledge or hesitation as to what the "world of science" actually is. Yet, Samantha was the only one interviewed who clearly put into words what science meant to her: "learning and teaching about chemistry, poison, germs and stuff like that” (P2PI, August 4, 2009).

When asked about what they initially thought of when they thought of science, other youth answered "test tubes" (Gregory, IN, Michael, nI, Eric, IN, P2PI, August 4, 2009), "books... text books" (Bradley, nI, R2PI, August 6, 2009) and "Einstein and lab coats" (Florence, IN, field notes, July 27, 2009). This led me to believe that their understanding and perception of science was one that was very much rooted in the stereotypes that effuse from Western science. It is understandable that youth such as Samantha (IN) do not want to associate themselves with the stereotypical lab-coat-wearing, middle-aged, white male whose time is spent in the laboratory (i.e., "nerds"). It is for this reason that WMS is occasionally referred to as White Male Science with tongue-in-cheek (Pomeroy, 1994). Furthermore, these stereotypes may make it difficult for many youth to later see themselves within the field of science or even within a lab coat. With this said, Florence eventually rescinded her comment regarding the lab coats when she gave it more thought. She noted that you did not necessarily have to wear a lab coat to do science. Even if the lab coat is only a stereotype, Barnhardt and Kawagley $(2005,2008)$ state that 
it is often the case that Indigenous youth within the science classroom are expected to learn and conform to the language, practices, and culture of Western science at the expense of their own Indigenous science.

It is interesting to note that Samantha (IN), once removed from her peer group, had a good laugh when confirming her earlier statement about science probably being for nerds. Despite this, she then stated that she in fact enjoyed science at school: "Yeah, it's fun... because...we do experiments" (Samantha, R2PI, August 5, 2009). Like some of the other participants, Samantha had experiences that were memorable and involved. For Michael (nI) it was microscopes. For Bradley (nI) it was "doing experiments [with] vinegar and baking soda... [making] stuff, [and going] outside” (R2PI, August 6, 2009). For Katherine (nI) it was also experiments "to see how everything reacts with each other. It's fun to see the chemicals and everything” (R2PI, August 5, 2009). In the following passage Samantha recounts her experience of an in-class boat design challenge:

We were using play-doh or something, like, we made a boat of it and then we put it in water, and then we were seeing how many pennies we can put in it, like, some people had more than a hundred. Some people only had 40 pennies in their boat. (R2PI, August 5, 2009)

Despite having had positive experiences with science, the participants' general understanding and perception of science suggests the Western, Eurocentric pedagogical nature of school science: namely rote-work (Aikenhead, 2006a; Barnhardt \& Kawagley, 2005, 2008; Holbrook \& Rannikmae, 2007). With reference to the school science education he had received so far, Gregory(IN) made such an experience succinctly clear when he articulated the following: "I like the stuff we're learning but I don't really like how we're learning it" (R2PI, August 6, 2009). Inquiring further into why he didn't enjoy how he was learning science in school, he replied that he does not "like doing textbook stuff" (P2PI, August 4, 2009). When this "textbook stuff” evokes stereotypical images of scientists for students in the classroom, it portrays the practices that scientists actually engage in as "probably for nerds" through negative association.

It is often argued that school science practices do not reflect practices that scientists undertake, but rather reflect myths of science (Aikenhead, 2006a; Aikenhead \& Michell, 2011; Aikenhead \& Ogawa, 2007; McComas, 1998). For example, school science is decontextualized, whereas science done by scientists is always "knowledge in context" (van Eijck \& Roth, 2007, p. 934). Furthermore, school science is viewed as strictly procedural, whereas the processes that scientists work through involve a great deal of creativity (McComas, 1998; see also Cajete, 1999). One of the "mythical" procedures that is often portrayed within school science is "the scientific method." Wong and Hodson (2009) speak to how "the scientific method" is more a classroom construct than something that scientists do (see also Aikenhead \& Michell, 2011; McComas, 1998).

For educators looking to teach Western modern science in their classrooms in way that is both relevant and realistic, Aikenhead (2006a) offers the following advice. First, he suggests that scientific values are articulated. This means teaching not only the "big ideas" but also teaching about the human, social, and cultural dimensions of the field of science. Here, we can also speak 
to the ways in which evidentiary practices are defined within the community. Secondly, he suggests that scientific practices be contextualized within both local and global contexts. Also, focusing on the socio-political, economical, and ethical dimensions which shape science and the scientific community can help science teachers reflect what scientists do in their classroom. Furthermore, Wong, Pugh, and the Dewey Ideas Group at Michigan State University (2001) suggest that school science should not only represent the mental processes involved in thinking like a scientist but also the heart and soul. In this manner, learning science goes beyond being relevant and becomes a meaningful and memorable experience. This sort of experience is "the pedagogical antidote to rote learning," it is a way of "thinking like a scientist” (Wong et al., 2001, p. 319) that is very human.

So long as school science continues to rely on the stereotypes of science such as procedural work, science will remain for many youth a culture to be avoided. Through this lens, scientists are seen as "nerds" and remain an identity to which youth associate a stigma. Nonetheless, some of this stigma can be addressed by teaching Western modern science by portraying it as a community practice that works in a variety of socio-political contexts. By portraying what scientists do and the embodied ways in which they do it, youth might better see themselves as participants in the world of science.

\section{What Counts as Science for Nunavut Youth}

Knowing that participants had very mixed feelings about science at school, I asked them if they did any activities that they considered science or science-related outside of their school time. Here are a few examples:

Samantha (IN):“I used to do experiments in my kitchen.” (R2PI, August 5, 2009)

Michael (nI): “Camera stuff.” (R2PI, August 5, 2009)

Bradley, (nI): I make volcanoes out of vinegar and that stuff [baking soda]. (R2PI, August 6, 2009)

The bulk of the responses resemble what I have noted above in that they are reflective of the types of activities that would be delivered within a science or technology classroom. When asked about informal activities that they would consider science, participants reported a few examples of learning that were less prescribed:

Bradley (nI): “Outside of school?...uh...physics? Well, I admire like...it’s really cool how you just ... well... like... you know how the airplane doesn't need wheels to take off, it just needs the propeller....We went camping one time and one flew right over us.” (R2PI, August 6, 2009)

Gregory (IN): “Um...sometimes I play with water!” (R2PI, August 6, 2009)

What is most interesting is the contrast between the two participants who stated they did not do any science-related activities outside of school, for different reasons. At first, I thought when 
they did not answer my interview prompt that it might be because they needed examples of science-related activities but this was not the case:

Marc: "Do you like doing science-related stuff outside of school?...like do some experiments in the kitchen, or go for a nature walk, or play pool then kind of really think about how you're hitting the ball and how everything plans out and stuff like that."

Eric(IN): “Yeah, but I don’t think about it.” (R2PI, August 5, 2009)

For Eric (IN) science was something that he acknowledged as embedded in his everyday life despite not "thinking about it." When asked the same question, Katherine (nI) replied: "I don't really consider it science” (R2PI, August 5, 2009). In Eric's case this might speak to the notion that an Indigenous science is a form of living with the world and that the knowledges and practices that flow from this are tacit. In Katherine's case this might speak to how strongly notions of "what counts as science" are embedded and enforced within Western culture (Frayn, 2006; Peat, 2002).

Notions of "what count as science" are deeply intertwined with the notion that within the science classroom "the implicit curriculum message is that the only science is [W] estern science" (Hodson, 1993, p. 686). With this comes the baggage of school science as abstracted, objective and decontextualized from everyday practices be they social, political, economical, cultural or moral (Aikenhead, 2006a). For many theorists and science educators this instrumental view is what is understood as "quality science." It is "inquiry characterized by reliability on evidence and reason with the goal of understanding an objective, external, physical world" (Southerland, 2000, p. 290; see also Cobern \& Loving, 2001, 2007; Matthews, 1994; Siegel, 1997, 2001).

What is understood to be "quality science" by certain (Western) theorists is inherently at loggerheads with what is entailed by "providing equitable opportunities for culturally diverse students" (Atwater \& Riley, 1993, p. 664). Educators who hold such an operational definition of science often end up teaching science without recognizing their students' everyday lived experiences as potentially rich sites for understanding nature. It is for this reason that scholars like Ogawa (1995) suggest we move towards defining science in more flexible manner such that science is "a rational perceiving of reality” (p. 588). Ogawa's definitions and others like his have been and often continue to be a point of tension as many scholars take the notions of "evidence and reason" to be universal. Lewis \& Aikenhead (2001) argue that these tensions have strong Eurocentric underpinnings and go on to define Eurocentrism as

the idea that the people, places, and events of Western European cultures are superior and a standard against which other cultures should be judged. Conversely, nonWestern cultures are inferior, and relevant only if they have a relationship to Western culture. (p. 53)

As the result of the Eurocentric lens that often shapes discussions around science, non-Western ways-of-knowing are not held as concurrent systems, not because of their value but because of how they are valued. It is for this reason that many scholars call for the continued examination of 
the often Eurocentric "nature of science" as a component of science curriculum (Plakitsi, 2010; Rudolph, 2000; Sammel, 2009).

Many of the youth participating within this research demonstrated signs of being both open and ready to engage in this sort of examination. For example, Michael's (nI) views of what counts as science are broader than what a textbook would include, while not excluding such content:

There's the microscope thing, and the computer technology stuff, and then the lab stuff, and then the out on the water and the land stuff, and then the...people who are like...outside, doing all that stuff, and then there's the people that are inside doing all that stuff. There's that plant stuff. Lots of stuff. (Michael, nI, R2PI, August 5, 2009)

Michael's (nI) views of what counts as science are in full growth. In adopting a view of science that is flexible and open, he may be better positioned to be an ally in the future (Barker, 2010).

\section{Who Can do Science (as Well as When and How)}

Despite participants not wanting to see themselves in "the world of science," it was well agreed upon by all interview participants (six out of six, R2PI) that science was something that everyone could do. When further elaborating as to why they believed this, participants said:

Samantha (IN): “Because it's not a ... a superhero [power]... it’s not like magic... it's just science. (R2PI, August 5, 2009)

Bradley (nI): “Because, like, anyone can be a part of it.” (R2PI, August 6, 2009)

The above answers speak to the idea that one can do science if one chooses to do it. Youth recognize that they do not have to be "Einstein" in a "lab coat." It is clear through what the participants voiced that they are not avoiding science because it is something that they cannot themselves do, but rather that it is something that they do not wish to do. They do not want science, at least in the way that it is presented to them through the school science that they have received (Aikenhead, 2004; Aikenhead \& Jegede, 1999; Jegede \& Aikenhead, 1999). For both Inuit and non-Inuit participants, science is culture that they wish to avoid (Aikenhead, 1996; Calabrase Barton, 2002; Coburn \& Aikenhead, 1998). This may be in part because of how science is done.

On the issue of science and how it is done, Gregory (IN) and Eric (IN) had a bit of a different take on the matter. As earlier noted Eric did not think about doing science when he was doing science informally. This is an opinion that is also reflected in Gregory's comment:

Gregory (IN): “... because it’s just the little thing that you have to...just...do.” (R2PI, August 6, 2009)

Through this perspective, science could be viewed as something that is holistically interwoven into the fabric of everyday life. Indigenous science is centered in knowledge 
stemming from living with nature rather than learning about nature. "An Indigenous knower is intimately and personally interconnected with that it is they know" (Aikenhead \& Michell, 2011, p. 68). This type of learning is reflected within the process that is referred to as "coming-toknow" (Ermine, 1998) or "coming-to-knowing” (Peat, 2002). These expressions reflect the ongoing process through which many Indigenous people learn. It is learning through entering into a holistic relationship with knowledge. We can find a Western pedagogical model in Dewey (1916) that is analogous: "If the living, experiencing being is an intimate participant in the activities of the world to which it belongs, then knowledge is a mode of participation" (p. 393). Furthermore, we can speak of Polanyi's (1966) notion of tacit knowledge, whereby knowledge is to be acquired through experience and relationship with the thing to be known. Tacit knowledge also has some tenets similar to the ongoing Inuit learning of traditional ancient knowledge (Ingold, 2004). Coming-to-knowing differs from tacit knowledge in that it speaks of entering a relationship with knowledge, where knowledge exists independently of the human consciousness, like a spirit. Like other relationships, coming-to-knowing respects the notion that there are agreements and obligations to be met and that there is responsibility attached to the knowledge itself and the way it is learned (Peat, 2002). It is experiential learning with a built-in consciousness. In this context, science is "fully integrated into the whole of life and being" (Cajete, 1999, p. 84); science is not something you learn about, it is simply something you do.

\section{Contrasting Inuit Qaujimajatuqangit With Western Modern Science}

While all interview (R2PI) participants (six out of six) agreed that there were many ways in which science can be enacted and that technology could be used, I sought to explore where they viewed Inuit Qaujimajatuqangit fitting into the picture. Inquiring into this, I posed an example where both traditional knowledge and modern technology were contrasted:

Marc: "Let's say a father and a son go out boating and they each have their own boat and the father uses, like, the sun and the sky, and the direction of the waves to kind of find his way and the son is using a GPS and they both get to the same point- do you think they're both as good as one another?” (R2PI, August 6, 2009)

The answers below represent the general consensus that all of the participants had reached:

Gregory (IN): “They're pretty equal because the father, he’s using his knowledge and the son, he’s using modern technology to help him around.” (R2PI, August 6, 2009)

Katherine (nI): "Yeah, both ways, they work the same, they're just different.” (R2PI, August 6, 2009)

All interview (R2PI) participants (six out of six) believed that both approaches got the job done. Regardless of whether or not all participants perceived these two ways-of-knowing as science, they did all consider them as equivalent but different. On one hand, this speaks to the pervasiveness of Eurocentric diffusionism within school science. Eurocentric diffusionism can be defined as the colonizers' lens onto the world that actively measures everything to an internalized Western meter stick or measurement system. Eurocentric diffusionism erases and silences everything that is not Western or understood as European-sensible (Blaut, 1993; 
Battiste, 2005; Henderson, 2000). It is plausible that Inuit traditional knowledge has been erased or silenced from participants' science classrooms. This discourages practices through which IQ is "counted" as science within the classroom. This further entrenches science as a culture to be avoided for Inuit youth as it does not reflect or respect their culture, their traditions or their beliefs (Barnhardt \& Kawagley, 2005, 2008). On the other hand, it is deeply encouraging to see that despite such classroom practices, the participants still view IQ and WMS as distinct yet equally valuable ways-of-knowing. This indicates that both Inuit and non-Inuit youth are well positioned, ready and willing to engage in cross-cultural dialogue within their science classrooms.

Not only are youth well equipped to engage in interfacing different ways-of-knowing, but also, they might be in a position to do so, critically. The youth demonstrated the ability to compare, contrast, and navigate between two different ways of interacting with nature. Some commented on how both approaches, while being functional, might have their ups and downs:

Eric (IN): "I think the GPS would be better in the winter in the North because the sun wouldn’t come up; it’ll just be up a couple hours a day.” (R2PI, August 5, 2009)

Bradley (nI): "Yeah, because the sun and the stars are a good way because but...except when it's in the daytime but a GPS it can’t really...in a storm you can't really take off your gloves...but you can still see the stars....Because sometimes, in like a whiteout, you can't see that...but like, the battery could turn off but...in the GPS. So then, both have ups and downs.” (R2PI, August 6, 2009)

In comparing and contrasting between IQ and WMS, the participants were able to smoothly and easily cross between the different ways-of-knowing that are strongly present within their community of Iqaluit. Video data of the interview (R2PI) indicates that this process required serious reflection. This may be a reflection of the higher level thinking that is required in the process of border crossing between bodies of scientific knowledge (Aikenhead, 2001; Fleer, 1997). Nonetheless, the participants appeared to have a significant understanding of how these distinct forms of knowledge each had their time, place, and purpose. Perhaps this is the result of the rich cross-cultural environment in which they live. It could be argued that both Inuit and nonInuit participants displayed evidence of an internal dialogue between these bodies of knowledge (see Mazzocchi, 2006; Peat, 2002). Despite IQ being either erased or underrepresented and WMS being misrepresented within the school science curriculum, youth may have implicitly or tacitly interfaced the two ways-of knowing. This is a rich stepping-stone from which science teachers can facilitate further cross-cultural scientific learning.

At the same time, it is interesting to note how Eurocentrism creates barriers for nonIndigenous youth to engage in this cross-cultural dialogue (Lewis \& Aikenhead, 2001; Mazzochi, 2006). For example, let us take a look at how Katherine (nI) speaks to the idea that knowledge is culturally based when comparing and contrasting IQ and WMS:

Katherine (nI): "Yeah, probably... like ... like, just people even just looking at the time, they look at the sun sometimes and stuff so whatever... that's the knowledge and it's not like ... modern stuff ... so everything just works together but it must be a 
lot harder to do it... the Inuit way because ... like, GPS just says it in front of you, but you actually have to think for the other part.” (R2PI, August 6, 2009)

Earlier, Katherine (nI) demonstrated that she upheld some of the Western tenets of "what counts as science." As a non-Inuit person, she is less likely to experientially learn open-water wayfinding techniques that stem from place than she is to learn how to use electronic device interfaces that are becoming ever more prevalent in Western culture. While she is not denouncing the traditional ways-of-knowing linked to place, she speaks of the "universality" that the GPS device can offer. As Eurocentrism often shape discourses of "universality" and "instrumentality" (e.g., what works "best"), what is usually seen as "best" science is Western science (Lewis \& Aikenhead, 2001; Snively \& Corsiglia, 2001; Stanley \& Brickhouse, 2001). This is how the "nature of science" acts as a gate-keeping device, preventing the two bodies of knowledge from fully interacting in a dialogical manner. It is for this reason that many educational scholars engage postcolonial resistance around the "nature of science" and encourage that this resistance also be a curricular act (Kanu, 2006; Rudolph, 2000).

In contrast, Michael (nI) took this opportunity to critique the culture of Western science as un-relational, non-reciprocal, and disrespectful. As a non-Inuit person, Michael made it clear that he did not see himself as a part of, nor did he want to be a part of, Western science. As he talked about scientists tracking beluga whale populations, he spoke of them jumping to conclusions rather than consulting Inuit people who have in-depth knowledge of beluga migration patterns, that they "have to look at it better instead of just trying to make up excuses" (Michael, nI, R2PI, August 5, 2009).

For non-Indigenous youth as well as non-Indigenous teachers working within a crosscultural space, this acknowledgement and critical reflection of the nature of Eurocentric thought is an important first step when it comes to learning about other ways-of-knowing (Belczewski, 2009; Strong-Wilson, 2007). Through this process, they can become more aware of the interplay between the Western Cartesian dualism which seeks to divide Indigenous ways-of-being and the Indigenous knowledges which live in everyday practices (Kincheloe, 2006). When both nonIndigenous youth and teachers begin to see how IQ and WMS are interconnected and were they depart, they are taking steps which make it possible for them to broaden their horizons.

Through comparing and contrasting Inuit Qaujimajatuqangit and Western modern science, both Inuit and non-Inuit participants alike recognized that these two ways-of-knowing the natural world are equal but distinct. Cross-cultural school science, drawing from the knowledges which stem from place, not only responds to the various needs of students who live there but it also leads to higher level thinking (Aikenhead, 2001, 2006b, Fleer, 1997). Nonetheless, such a hybrid education must be assembled and taught with care. The pervasiveness of Eurocentric thought too often subjugates Indigenous knowledges through erasure and devaluation within the science classroom (Barnhardt \& Kawagley , 2005, 2008; Kincheloe, 2006). 


\section{Conclusion: Pedagogical Possibilities When Frequencies are in Phase}

If we are to seriously take up the Nunavut Department of Education's (2000a, 2000b) call to balance Western educational approaches and Inuit Qaujimajatuqangit within schools, there are specific possibilities and problems that arise within the science classroom. The interfacing of IQ and Western modern science is often referred to one of "Jagged Worldviews Colliding" (Little Bear, 2000) due to features that are seen as irreconcilable. Furthermore, there is much work needed in rebalancing curriculum. In its current state, the Western modern science practices which permeate youth's everyday lives are misrepresented (Aikenhead 2006a; Aikenhead \& Ogawa, 2007; McComas, 1998) and the Indigenous knowledges shaped by the places in which they live are either underrepresented or not represented at all (Cajete, 1999; Barnhardt \& Kawagley, 2005, 2008). It is nonetheless worth striving for as a balanced cross-cultural science education has much to offer to all students. Science education and the scientific literacy resulting from it can be both empowering and emancipatory (Barton, Ermer, \& Burkett, 2003; Hodson, 2003, 2005; Millar, 2006; Ratcliffe \& Grace, 2003). While all youth can gain from an increased scientific literacy, this might especially be the case for Indigenous youth (Snively \& Williams, 2006).

It is not only the science content taught in Nunavut schools that is in need of change, but also the way in which the science is taught. While there are many ways of bridging cultures, one of the methods that is often suggested is that of border crossing (Aikenhead, 2001; Giroux, 1992, 2005). Within the context of this research, participants did not want to border cross into the "world of science" as it is defined within the science classroom. Comments from Nunavut youth participants in this study resonate with the well-documented phenomena that many (>90\%) students do not want to think like scientists and actively avoid the Eurocentric culture of school science (Aikenhead, 2004; Aikenhead \& Elliot, 2010; Fensham, 2004). Relying largely on stereotypes and myths of science, school science remains abstracted (i.e., "for nerds") and rooted in rote work (i.e., "boring”).

Nonetheless, border crossing can be an effective teaching and learning metaphor. From this study, I offer four major suggestions in making border crossing science education more meaningful and memorable. First, in making Western modern science realistic and relevant, it needs to be taught in a manner that reflects the embodied nature of what scientists do. Here WMS needs to be taught as a culture unto itself in which communities of practitioners creatively operate in social, political, ethical, and economical contexts. Second, the "culture of science" has values that are often rooted in Eurocentrism which could and should be points of analysis within a curriculum. Through such a critique, students can actively transform "what counts as science" so that it better reflects some of their everyday interactions with the natural world. Third, just as there is much content that can "count as science," there are multiple ways of learning science. Science needs to be taught in a way that recognizes and honours epistemologies such as comingto-knowing. Lastly, in order for border crossing to be effective and respectful, it needs to be balanced and bi-directional. Care must be taken in how and when IQ and WMS are interfaced given the pervasive nature of Eurocentrism. For Inuit students, this is essential as "science" should not be learned at the expense their cultural knowledge. For non-Inuit students, Eurocentrism can act as blinders which prevent the broadening of horizons. Overall, science 
education needs to nurture the whole student in relation to their community of practice, to the people and places where they live and the knowledges found there.

There is growing acknowledgement that Indigenous and Western science are distinct yet equally valid paths that can be walked upon in order to generate understanding. As Indigenous knowledge and ways-of-knowing are increasingly recognized as adaptive means of addressing complex systems (Bartholomew, 2003) and Western modern science continues its emerging focus on relationships and interconnectedness there will be an increasing awareness of the commonalities between the two different bodies of knowledge. As Barnhardt and Kawagley (2005) state: "There is a growing appreciation of the complementarity that exists between what were previously considered two disparate and irreconcilable systems of thought” (p. 12). This is a sentiment Peat (2002) also shares:

It is at this point that a tantalizing paradox presents itself. On one hand it seems that the very activity and busy-ness of our analytic, linear Western minds would obstruct us from entering into Indigenous coming-to-knowing, yet, on the other, scientists who have been struggling at the cutting edges of their fields have come up with concepts that resonate with those of Indigenous science. (p. 6)

Watt-Cloutier (2004) states that complimentarity is not only possible but also necessary in the context of climate change:

We all know that the Arctic and Inuit are navigating rapid changes very quickly. In the midst of this change we need to be both resilient and adaptive. The connectedness of our world demands this. I think this is another way of saying our [Inuit Qaujimajatuqangit] and your [Western modern science] go together. (p. 303)

Scientific practices are shifting towards cross-cultural dialogues. Inuit and non-Inuit youth demonstrate the willingness and ability to engage in these sorts of dialogues. There is no better time for our educational practices within schools to reflect this commitment to working across difference in how we learn about, through and with nature. 


\section{References}

Aikenhead, G. S. (1996). Science education: Border crossing into the subculture of science. Studies in Science Education, 26, 1-52.

Aikenhead, G. S. (1997). Toward a First Nations cross-cultural science and technology curriculum. Science Education, 81, 217-238.

Aikenhead, G. S. (2001). Students' ease in crossing cultural borders into school science. Science Education, 85, 180-188.

Aikenhead, G. S. (2004). The humanistic and cultural aspects of science \& technology education. A plenary paper presented to the $11^{\text {th }}$ International Organization for Science and Technology Education (IOSTE) Symposium Lublin, Poland, July 25-30, 2004.

Aikenhead, G. S. (2006a). Science education for everyday life. London, ON: Althouse Press.

Aikenhead, G. S. (2006b). Cross-cultural science teaching: Rekindling traditions for Aboriginal students. In Y. Kanu (Ed.), Curriculum as cultural practice: Postcolonial imaginations (pp. 223-248). Toronto, ON: University of Toronto Press.

Aikenhead, G., \& Elliot, D. (2010). An emerging decolonizing science education in Canada. Canadian Journal of Science, Mathematics and Technology Education, 10(4), 321-338.

Aikenhead, G. S., \& Jegede, O. J. (1999). Cross-cultural science education: A cognitive explanation of a cultural phenomenon. Journal of Research in Science Teaching, 36, 269287.

Aikenhead, G. S., \& Michell, H. (2011). Bridging cultures: Indigenous and scientific ways of knowing nature. Toronto, ON: Pearson Canada Inc.

Aikenhead, G. S., \& Ogawa, M. (2007) Indigenous knowledge and science revisited. Cultural Studies of Science Education, 2(3), 539-91.

Atwater, M. M., \& Riley, J. P. (1993). Multicultural science education: Perspectives, definitions, and research agenda. Science Education, 77(6), 661-668.

Aylward (2007). Discourses of cultural relevance in Nunavut. Journal of Research in Rural Education, 22(7).

Barker, A. (2010). From adversaries to allies: Forging respectful alliances between Indigenous and settler peoples. In L. Davis (Ed.) Alliances: re/envisioning Indigenous-non-Indigenous relationships (pp. 316-333). Toronto, ON: University of Toronto Press.

Barnhardt, R., \& Kawagley, A. (2005). Indigenous knowledge systems and Alaska Native ways of knowing. Anthropology and Education Quarterly, 36(1), 8-23. 
Barnhardt, R., \& Kawagley, A. (2008). Indigenous knowledge systems and education. Yearbook of the National Society for the Study of Education, 107(1), 223-241.

Barton, A.C., Ermer, J. L., \& Burkett, T. A. (2003). Teaching science for social justice. New York: Teachers College Press.

Bartholomew, D. (2003). Indigenous education (theme issue). Cultural Survival Quarterly, 27(4).

Battiste, M. (2005). You can't be the global doctor if you're the colonial disease. In P.Tripp, \& L.J. Muzzin (Eds.), Teaching as Activism (pp. 121-133). Montreal, QC: Queen’s University Press.

Belczewski, A. (2009). Decolonizing science education and the science teacher: a while teacher’s perspective. Canadian Journal of Science Education, 9(3), 191-202.

Berger, P. (2007). Some thoughts on Qallunaat teacher caring in Nunavut. Journal of Teaching and Learning, 4(2), 1-12.

Blaut, J. (1993). The colonizer's model of the world: Geographical diffusionism and Eurocentrichistory. New York: Guilford Press.

Brayboy, B. M. J., \& Castagno, A. (2008). How might Native science inform “informal science learning”? Cultural Studies of Science Education, 3, 731-750.

Cajete, G. A. (1999). Igniting the sparkle: An Indigenous science education model. Durango, CO: Kivaki Press.

Calabrese Barton, A. (2002). Urban science education studies: A commitment to equity, social justice and a sense of place. Studies in Science Education, 38, 1-38.

Cobern, W. W., \& Aikenhead, G. S. (1998). Cultural aspects of learning science. In B.J. Fraser \& K.G. Tobin (Eds.), International handbook of science education (pp. 39-52). Dordrecht, Netherlands: Kluwer Academic Publishers.

Cobern, W. W., \& Loving, C. C. (2001). Defining “science” in a multicultural world: Implications for science education. Science Education, 85, 50-67.

Cobern, W. W., \& Loving, C. C. (2007). An essay for educators: epistemological realism really is common sense. Science \& Education, 17, 425-447.

Dewey, J. (1916). Democracy and education: An introduction to the philosophy of education. New York: MacMillan. 
Ermine, W. (1998). Pedagogy from the ethos: An interview with Elder Ermine on language. In Stiffarm (Ed.) As we see...Aboriginal pedagogy (pp. 9-28). Saskatoon, SK: University of Saskatchewan Extension Press.

Fensham, P. (2004, September 23/24). Engagement with science: An international issue that goes beyond knowledge. Lecture given at the Science and Mathematics Education Conference, Dublin City University/St Patrick's College, Dublin.

Fleer, M. (1997). Science, technology and culture: supporting multiple worldviews in curriculum design. Australian Science Teacher's Journal, 43.

Frayn, M. (2006). The human touch: Our part in the creation of the universe. New York: Metropolitan Books.

Giroux, H. (1992). Border crossings: Cultural workers and the politics of education. New York: Routledge.

Giroux, H. (2005). Border crossings: Cultural workers and the politics of education, (2nd ed.). New York: Routledge.

Henderson, J. Y. (2000). Postcolonial ghost dancing: Diagnosing European colonialism. In M.A. Battiste (Ed.), Reclaiming indigenous voice and vision (pp. 56-76). Vancouver: UBC Press.

Hickling-Hudson, A., \& Ahlquist, R. (2003). Contesting the curriculum in the schooling of Indigenous children in Australia and the United States: From Eurocentrism to culturally powerful pedagogies. Comparative Education Review, 47, 64-89.

Higgins, M. (2010). Decolonizing actions that speak louder than words: Science education through multiple lenses in Nunavut (Master's thesis). Lakehead University, Thunder Bay, ON.

Hodson, D. (1993). In search of a rationale for multicultural science education. Science Education, 77(6), 685-711.

Hodson, D. (2003) Time for action: Science education for an alternative future. International Journal of Science Education, 25(6), 645-670.

Hodson, D. (2005). What is scientific literacy and why do we need it? The Morning Watch, 33(12).

Holbrook, J., \& Rannikmae (2007). The nature of science education for enhancing scientific literacy. International Journal of Science Education, 29(11), 1347-1362.

Ingold, T. (2004). Foreword. In D. G. Anderson \& M. Nuttall (Eds.), Cultivating Arctic landscapes: Knowing and managing animals in the circumpolar north (pp. viii-xiii). Oxford: Berghahn Books. 
Jegede, O. J., \& Aikenhead, G. S. (1999). Transcending cultural borders: Implications for science teaching. Research in Science and Technological Education, 17, 45-66.

Kanu, Y. (2003). Curriculum as cultural practice: Postcolonial imagination. Journal of the Canadian Association for Curricular Studies, 1(1), 67-81.

Kanu, Y. (Ed.),(2006). Curriculum as cultural practice: Postcolonial imaginations. Toronto, ON: University of Toronto Press.

Kawagley, O., Norris-Tull, D., \& Norris-Tull, R. (1998). The Indigenous worldview of Yupiaq culture: Its scientific nature and relevance to the practice and teaching of science. Journal of Research in Science Teaching, 35(2), 133-144.

Kincheloe, J. L. (2006) Critical ontology and Indigenous ways of being: forging a postcolonial curriculum. In Y. Kanu (Ed.), Curriculum as cultural practice: Postcolonial imaginations (pp. 181-202). Toronto, ON: University of Toronto.

Leap, W. (1982). Dimensions of math avoidance among American Indian elementary school students. Washington, DC: National Institute of Education.

Lewis, B., \& Aikenhead, G. (2001). Introduction: Shifting perspectives from universalism to cross-culturalism. Science Education, 85, 3-5.

Little Bear, L. (2000). Jagged worldviews colliding. In M. Battiste (Ed.), Reclaiming Indigenous voice and vision (pp. 77-85). Vancouver: University of British Columbia.

Mason, R. (2006). A kinder mathematics for Nunavut. In Y. Kanu (Ed.), Curriculum as cultural practice: Postcolonial imaginations (pp. 131-148). Toronto: University of Toronto Press.

Matthews, M. R. (1994). Science teaching: The role of history and philosophy of science. New York: Routledge.

Mazzocchi, F. (2006). Western science and traditional knowledge. EMBO reports, 7(5), 463-466.

McComas, (1998). The principal elements of the nature of science: Dispelling the myths. In W. F. McComas (Ed.) The nature of science in science education (pp. 53-70). Netherlands: Kluwer Academic Publishers.

Millar, R. (2006). Twenty first century science: Insights from the design and implementation of a scientific literacy approach in school science. International Journal of Science Education, 28(13), 1499-1521.

Nunavut Department of Education. (2000a). Program and curriculum management strategy. Iqaluit, Nunavut: Author. 
Nunavut Department of Education. (2000b). Inuit Qaujimajatuqangit: A new philosophy for education in Nunavut. Iqaluit, Nunavut: Author.

Nunavut Social Development Council (1998). 5.32 Article 32.

Ogawa, M. (1995). Science education in a multiscience perspective. Science Education, 79, 583593.

O’Loughlin, M. (1992). Rethinking science education: Beyond Piagetian constructivism toward a sociocultural model of teaching and learning. Journal of Research in Science Teaching, 39, 791-820.

Peat, D. (2002). Blackfoot physics: A new journey into the Native American universe. Newbury Port, MA: Weiser Books.

Phelan, P., Davidson, A., \& Cao, H. (1991). Students' multiple worlds: Negotiating the boundaries of family, peer, and school cultures. Anthropology and Education Quarterly, 22, 224-250.

Plakitsi, K. (2010). Collective curriculum design as a tool for rethinking scientific literacy. Cultural Studies of Science Education, 5(3), 577-590.

Polanyi, M. (1966). The tacit dimension. Garden City, NY: Doubleday \& Co.

Pomeroy, D. (1994). Science education and cultural diversity: Mapping the field. Studies in Science Education, 24, 49-73.

Ratcliffe, M., \& Grace, M. (2003). Science education for citizenship: Teaching socio-scientific issues. Milton Keynes, England: Open University Press.

Rudolph, J. L. (2000). Reconsidering the 'nature of science' as curriculum component. Journal of Curriculum Studies, 32(3), 403-419.

Sammel, A. (2009). Turning the focus from 'other' to science education: Exploring the invisibility of Whiteness. Cultural Studies of Science Education, 4, 649-656.

Siegel, H. (1997). Science Education: Multicultural and universal. Interchange, 28, 97-108.

Siegel, H. (2001). Multiculturalism, universalism, and science education: In search of common ground. Science Education, 86, 803-820.

Snively, G., \& Corsiglia, J. (2001). Discovering Indigenous science: Implications for science education. Science Education, 85, 6-34.

Snively, G., \& Williams, L. (2006). The Aboriginal knowledge and science education research project. Canadian Journal of Native Education, 29(2), 229-244. 
Southerland, S. A. (2000). Epistemic universalism and the shortcomings of curricular multicultural science education. Science \& Education, 9, 289-307.

Stanley, W. B., \& Brickhouse, N. W. (1994). Multiculturalism, universalism, and science education. Science Education, 78, 387-398.

Stanley, W. B., \& Brickhouse, N. W. (2001). Teaching sciences: The multicultural question revisited. Science Education, 85, 35-49.

Statistics Canada. (2007). 2006 community profiles. Retrieved from http://www12.statcan.ca/census-recensement/2006

Strong-Wilson, T. (2007). Moving horizons: Exploring the role of stories in decolonizing the literacy education of white teachers. International Education, 37(1), 114-131.

van Eijck, M., \& Roth, W. M. (2007). Keeping the local local: Recalibrating the status of science and Traditional Ecological Knowledge (TEK) in education. Science Education, 91, 926-947.

Watt-Cloutier, S. (2004). Bringing Inuit and Arctic perspectives to the global stage: Lessons and opportunities. Proceedings of the 14th Inuit Studies Conference, (pp. 301-308).

Wong, E. D., Pugh, K. J., \& The Dewey Ideas Group at Michigan State University. (2001). Learning science: A Deweyan perspective. The Journal of Research in Science Teaching, 28, 317-336.

Wong, S.L., \& Hodson, D. (2009). From the horse's mouth: what scientists say about scientific knowledge. Science Education, 93, 109-130.

\section{Endnotes}

${ }^{1}$ See Higgins (2010) for further discussion on the project as a whole. 